\title{
Free Will Theodicies for Theological Determinists
}

\author{
T. Ryan Byerly ${ }^{1}$
}

Published online: 18 January 2017

C The Author(s) 2017. This article is published with open access at Springerlink.com

\section{Keywords Theodicy $\cdot$ Free will $\cdot$ Causal determinism $\cdot$ Molinism}

It is a widespread view in contemporary philosophy of religion that theists should adopt a libertarian theory of free action according to which there are free actions and free actions cannot be causally determined. ${ }^{1}$ This is because, by doing so, theists will be far better equipped to respond to the most important objection to theism - the problem of evil - than if they do not. The ubiquity of this narrative is certainly due, in part, to the influential work of authors Alvin Plantinga, Richard Swinburne, and John Hick who have articulated well-developed and highly regarded theodicies according to which it either could be or plausibly is the case that God could not achieve certain goods without permitting evils. ${ }^{2}$ The goods these authors have in mind are freedom goods-goods only achievable via free action on the part of creatures - and the evils they have in mind include both evils for which created agents are morally responsible (i.e., moral evils) and evils for which created agents are not morally responsible (i.e., natural evils). ${ }^{3}$ In the course of presenting their theodicies, these authors all explicitly affirm a libertarian theory of free action. Their doing so has given the impression that this commitment to libertarianism is required in order to advance their theodicies. And, because of the promise of their theodicies, many have concluded that theists who hope for a response to the problem of evil are best off being libertarians.

\footnotetext{
${ }^{1}$ This is evidenced by, for example, the 2009 Philpapers Survey, which revealed that a disproportionate percentage of philosophers inclined toward theism are also inclined toward libertarianism. The results of the survey are available at philpapers.org.

${ }^{2}$ For a detailed presentation of the role that these authors' work has played in bringing it about that the view that theists should be libertarians is so common, see (Speak and Timpe 2016).

${ }^{3}$ For my purposes here, it will not be necessary to distinguish these categories from a potential third category of social evil [on the latter, see (Poston 2014)]. This is because my aim is to show that the theodicies offered by the authors with whom I engage can be adapted by theological determinists to account for the same kinds of evils that these authors have in view, and these authors have in view only moral and natural evils.
}

T. Ryan Byerly

t.r.byerly@sheffield.ac.uk 
In this paper, I will challenge the view that libertarianism is necessary in order to adopt the theodicies of Plantinga, Swinburne, and Hick. ${ }^{4}$ I will show that a theist who affirms that all the free actions that exist are causally determined (a theological determinist, as I will stipulatively define the view) ${ }^{5}$ can adopt quite a lot from the approaches of these authors. More specifically, she can employ the basic argumentative strategies most central to these authors' projects in order to offer accounts of why it could have been or plausibly is the case that God could not have achieved certain freedom goods without permitting various moral and natural evils. She can use their strategies, that is, to offer free will theodicies. I will not argue that by employing these strategies she will achieve free will theodicies that are equally as plausible as any free will theodicy a libertarian can offer. Nor will I argue that in every particular case in which she adopts the strategies of Plantinga, Swinburne, and Hick, she is able to produce a free will theodicy for certain particular evils that is equally as attractive as the corresponding free will theodicy these authors are able to produce by using these strategies; though I think in many cases, she straightforwardly can do so and I will indicate where this is so below. My more modest aim, instead, is to show how theological determinists can make a promising start toward developing free will theodicies by adapting the strategies of these authors. The full development and evaluation of the free will theodicies for theological determinists that I articulate here is a task I hope to prompt readers to join me in pursuing in the near future.

My strategy for fulfilling this aim will be to engage with central argumentative strategies from the theodicies of each of the three authors one by one, beginning in the next section with John Hick. I should note here that I will not be engaging with each author's entire body of theodicy-relevant work. Rather, there are certain central aspects of their theodicy-relevant work that I believe are particularly promising starting points for theological determinists, and I will be focusing on those aspects. For Plantinga, I focus on his appeal to Molinism in order to offer a defense for moral evils. For Swinburne, I focus on his attempt to extend the free will defense to account for natural evils. And, for Hick, I focus on his appeal to character formation to account for natural evils. For each author, I present the basic argumentative strategy of the relevant part of his work and then show how that strategy could be employed by a theological determinist to offer a corresponding free will theodicy.

\section{Character Formation Free Will Theodicies for Theological Determinists}

Of the three authors considered in this paper, the one whose commitment to a libertarian conception of free action is least obvious is John Hick. Perhaps for that

\footnotetext{
${ }^{4}$ Some other authors have attempted to challenge this view as well, but not in the way I do here. See, e.g., (Judisch 2008), (Turner 2013), and (Almeida forthcoming).

5 The term 'theological determinism' is often used with a different meaning, requiring that all contingent facts are determined by the divine will. This is not a requirement of 'theological determinism' as I have defined it; however, much of what I will say in the paper is still relevant for such views. One important point of difference is that only a 'theological determinist' in my stipulative sense, and not in this other sense, can affirm the compatibilist Molinist view I discuss in "Greater Moral Goods Free Will Theodicies for Theological Determinists" section.
} 
reason, it will also be easiest to see how a theological determinist can adopt central aspects of his free will theodicy. ${ }^{6}$

As Dan Speak (2013) helpfully points out, Hick's commitment to libertarianism comes out most clearly in his discussion on the freedom of human persons to respond in love to God. For Hick, God cannot ensure that human persons will respond to him with the most valuable kind of love. This is because the kind of freedom necessary for this most valuable loving response requires that the response not be causally determined. As Hick explains, 'Whilst a free action [of the kind in view here] arises out of the agent's character it does not arise in a fully determined and predictable way. It is largely but not fully prefigured in the previous state of the agent. For the character is itself partially formed and sometimes partially re-formed in the very moment of free decision (1978: 276).' The fact that Hick affirms libertarianism here may lead some readers to think that adopting the central elements of his theodicy requires affirming libertarianism. At the very least, it is plausible that Hick himself is thinking of his claims about free action throughout his theodicy as involving a libertarian understanding. That is, when he discusses free action throughout his theodicy, it is plausible that he intends to be understood as referring to action types the occurrence of which is incompatible with causal determinism. Nonetheless, it is worth our while to consider whether central aspects of his theodicy could nonetheless be adapted by theological determinists, who by definition deny libertarianism and instead affirm compatibilismthe view that free actions can be causally determined.

The central aspect of Hick's theodicy on which I will focus, and probably the aspect for which his theodicy is best known, is his appeal to character formation, or soulbuilding, to account for natural evils. Hick argues that God must permit natural evils of the sort we find in our world if God is to achieve a world in which human persons engage in free acts whereby they inculcate virtuous characters. This is because, as Hick puts it, persons can only develop virtuous characters through their own free decisions if they are placed in an environment which includes 'challenges to be met, problems to be solved, dangers to be faced, and which accordingly involves real possibilities of hardship, disaster, failure, defeat, and misery (2001: 276).' It is only in such an environment, he claims, that persons can 'develop in intelligence and in such qualities as courage and determination (ibid).' Yet, acquiring a virtuous character via one's own free decisions leads to the most valuable kind of moral goodness, Hick maintains. Indeed, his theodicy is based on the principle that "virtues which have been formed within the agent as a hard won deposit of his own right decisions in situations of challenge and temptation, are intrinsically more valuable than virtues created within him ready made and without any effort on his own part (271).' In summary, Hick offers a free will theodicy according to which the freedom good of virtuous character formed through free actions productive of virtue is made achievable only by God's permission of natural evils. God plausibly would permit the natural evils that occur in our world because permitting them is required in order for this freedom good to be achieved.

This aspect of Hick's soul-building theodicy has been subjected to a variety of objections, which I will not rehearse here. ${ }^{7}$ I note only that in contemporary discussions of the problem of evil, Hick's theodicy continues to receive serious attention and is seen

\footnotetext{
${ }^{6}$ For another paper that argues that Hick's theodicy does not require libertarianism, see (Pereboom 2012).

${ }^{7}$ For a survey, see the relevant section of (Gelinas 2009).
} 
as a viable contender for at least contributing to a multifaceted theistic response to the problem of evil. ${ }^{8}$ If this aspect of his theodicy could be deftly adapted by theological determinists, this would make an important contribution to challenging the ubiquitous contemporary view that theists should be libertarians in order to adequately respond to the problem of evil. Theists could affirm theological determinism and employ an adaptation of Hick's free will theodicy to account for at least certain evils.

As it turns out, it is not difficult to see how a theological determinist could adapt this aspect of Hick's theodicy. For, she too may affirm that inculcating a virtuous character by means of performing free acts productive of virtue is a great freedom good. Moreover, she may think this is a freedom good that can only be achieved by God through permitting evils to occur. For, like Hick, she may think that it is only an environment in which there are challenges to be met, problems to be solved, and dangers to be faced that these character-forming actions can take place. The only difference between her and Hick is that she thinks that those free actions created agents perform in response to these evils are acts that are causally determined to occur. Hick may say these acts are for this reason not free, or do not exhibit the most valuable sort of freedom. But, since the theological determinist affirms that free action is compatible with causal determinism, she needs not concede this point. She may instead maintain that these causally determined acts are indeed free, and perhaps even that they exhibit the most valuable kind of freedom, and as such the goods achieved through them are freedom goods. According to her Hick-inspired free will theodicy, God permits certain natural evils because permitting them is required in order to make it possible for created persons to achieve the freedom good of cultivating a virtuous character through their own free decisions.

There is also a way in which the theological determinist might extend Hick's soulbuilding theodicy to at least partially account for some moral evils. For, while Hick focuses primarily on natural evils as those evils required in order for persons to cultivate virtuous characters via free action, one might think that there are certain virtues which are such that they can only be inculcated through free decisions if there are moral evils. In other words, there are some virtues that can only be developed in response to moral evils. Forgivingness and contrition are often thought of in this way. ${ }^{9}$ Whereas forgivingness disposes its possessor to respond well to moral evils done against her or against those to whom she is appropriately related, contrition disposes its possessor to respond well to moral evils done by her or by those to whom she is appropriately related. The theological determinist might then argue that certain moral evils are permitted by God at least in part because the occurrence of these moral evils is required in order for the perpetrators and victims of these evils to have an opportunity to develop virtues such as forgivingness and contrition through free actions productive of these virtues. ${ }^{10}$ Thus, the theological determinist can employ Hick's argumentative strategy to at least partially account for both some natural evils and some moral evils.

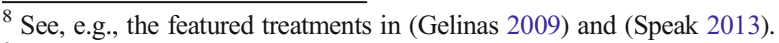

${ }^{9}$ For a recent survey of philosophical literature about forgivingness, see (McNaughton and Gerrard 2014).

${ }^{10}$ It is important to note here and elsewhere that a freedom good may contribute to the explanation for God's permission of an evil without being the only reason for which that evil was permitted. Indeed, some philosophers have argued that God does everything, God does for every good reason, and God has to do it. See, e.g., (Pruss 2013).
} 
Now, one might object that this theological determinist adaptation of Hick's soulbuilding theodicy is not as plausible as Hick's libertarian version. For, the theological determinist version fails to explain why it is that once the evils required for the free cultivation of virtue occur, created persons responding to these evils do not simply go on every last time to perform good free acts. Since the actions they take in the face of natural evils can be determined, one might have expected that God would ensure that only good acts are performed in every case. Yet, by contrast, on Hick's view, these free acts cannot be determined, and so it is not surprising that good responses to natural evils do not always occur. Thus, Hick's version of the soul-building theodicy is significantly more plausible than the theological determinist version.

While tempting, this particular objection to the above adaptation of Hick's soulbuilding theodicy is a red herring. The objector complains that the theological determinist version of this particular aspect of Hick's soul-building theodicy does not explain why created persons sometimes choose evil rather than good when faced with natural (and perhaps moral) evils required to give them an opportunity to develop their souls. But these moral evils - the evils of choosing badly when given opportunities to develop our souls - are not what the relevant aspect of the soul-building theodicy is designed to explain, supposing that these moral evils are not also among those required to provide created persons with opportunities for cultivating virtue. This is the case whether this aspect of the soul-building theodicy is wielded by Hick or by the theological determinist. For, regardless of who is employing this aspect of the theodicy, it is only designed to explain those evils that are required to provide created persons with opportunities to develop their souls. If there are other evils not required for providing created persons with opportunities for soul-building, such as evils that created persons perform by choosing to not respond well to natural evils, these must be accounted for through some other means.

This is not to say that Hick offers no such means anywhere else in the body of his work concerned with the problem of evil. ${ }^{11}$ Nor is it to say that the theological determinist who adapts Hick's soul-building theodicy is not under pressure to account for these evils in some other way as well. She very much is, and in "Greater Moral Goods Free Will Theodicies for Theological Determinists" section below, I will discuss two strategies she might employ in order to do so. The point here is simply that the aspect of the soul-building theodicy on which I have been focusing and the aspect which has been by itself enormously influential did not address these evils. As such, it is an equal opportunity theodicy, available to the theological determinist just as much as to the libertarian, and useful for at least partially accounting for some though not all evils. The evils that it is useful for explaining, for both the libertarian and

\footnotetext{
11 Though it is less than straightforward to identify Hick's view on the matter, a plausible interpretation of his view is that these moral evils are, or might be, required if human persons are to freely enter the most valuable kind of relational union with God, even if they are not required for human persons to freely cultivate their characters in the way discussed in the text (cf Speak 2013). Exactly how to defend the conclusion that such moral evils are required if God is to achieve a world in which human persons freely enter into union with Him is a difficult question to which several answers might be offered. I discuss resources relevant to developing one answer to it in "Greater Moral Goods Free Will Theodicies for Theological Determinists" section and argue that these resources can be adapted by theological determinists. I discuss resources relevant to offering another answer to it more briefly in "Conclusion" section, explaining that these resources cannot be adopted by theists committed to the doctrine of classical omniscience.
} 
the theological determinist, are those evils required to provide created persons with opportunities for freely cultivating virtues. This central aspect of Hick's work, then, can be employed to develop a character formation free will theodicy for theological determinists.

\section{Moral Knowledge Free Will Theodicies for Theological Determinists}

I turn next to a central aspect of the free will theodicy of Richard Swinburne. Specifically, I will focus on his free will theodicy for natural evils. I will identify four ways in which his strategy for arguing that natural evils are required for freedom goods can be adapted by theological determinists to account for both natural and moral evils.

Swinburne states very clearly in his seminal article on the topic of natural evil the commitment to libertarianism invoked by the standard free will defense. He writes, 'The free-will defense claims that God might well give to men a kind of free will in which how an agent acts is not fully determined by preceding causes but depends, at least in part, on the agent's uncaused choice at the instant of action (1978: 295).' Swinburne shares, and intends to be understood as sharing, this commitment to libertarianism. His stated thesis shows that the free will defense 'could only work in providing an explanation for why God allows moral evil, if in fact there is also natural evil (296).' In other words, Swinburne maintains that the freedom goods in view in the free will defense require the existence not only of moral evils but natural evils. As such, it is clear that he has in mind a libertarian conception of free action when we offers his free will theodicy for natural evil, since he is clear that the freedom goods in view in the free will defense are achievable only given a libertarian theory of free action. Thus, it is understandable that some readers may conclude that adopting libertarianism is essential in order to appropriate the basic strategy of his theodicy for natural evil.

Swinburne's free will theodicy for natural evil focuses on the freedom good of exercising significant control. On Swinburne's view, in order for human persons to achieve the freedom good of exercising significant control, they must have knowledge that some of their potential acts would result in goods while others of their potential acts would result in bads. More colloquially, Swinburne is committed to the view that moral knowledge is necessary for exercising significant control. This is because, in order to exercise significant control in some domain, one must, in Swinburne's terminology, have the opportunity to perform both morally good and morally bad acts within that domain. ${ }^{12}$ If one only has the opportunity to perform morally good acts in some domain, then the control over one's life that one exercises in that domain is not significant. However, if one is to have the opportunity to perform both morally good and morally bad acts in a domain, then one must have knowledge that at least some of one's potential acts in that domain would lead to good and that some of one's potential acts would lead to bad. Swinburne argues, however, that no human person could have knowledge that some of her potential acts would result in bads, and still have the

\footnotetext{
12 See his (1978: 300) for this usage of 'opportunity.' Charitably understood, Swinburne's talk of 'opportunity' is probably equivalent to what others would call opportunity and ability.
} 
opportunity to do both good and evil, unless there were past natural evils. He argues, to put it more colloquially, that natural evils are necessary for moral knowledge. ${ }^{13}$

To defend the claim that natural evils are necessary for moral knowledge, Swinburne argues that human persons will have to obtain this moral knowledge on the basis of induction from past cases, if they are to have the opportunity to do both good and evil. For example, if a person is to have the knowledge necessary to exercise significant control over her distribution of cyanide to others, she will have to know of past effects of cyanide for good and ill. This moral knowledge must be obtained via induction because the only other route to obtaining it would be on the basis of direct divine revelation, which would put persons in a position where they no longer have the opportunity to do both good and evil. Direct divine revelation would prevent persons from having the opportunity to do evil, Swinburne maintains, because such revelation would put its recipients in a position where they would have no reason to do otherwise than the good, since they would be constantly aware of God's looking over their shoulders. Yet, in order to have the opportunity to do both good and evil, one must have both reason to act the way one acts and reason to perform a moral alternative. So, moral knowledge must be achieved via induction from past cases.

Moreover, the past cases from which human persons gain the inductive moral knowledge necessary for exercising significant control must include natural evils. They cannot all be cases of moral evil. This is because, for each kind of moral evil, there must have been a first instance when that moral evil was committed. But, then, given that this moral evil was an exercise of significant control, which it must have been, ${ }^{14}$ it must have been that the person who committed the evil had the moral knowledge necessary for exercising significant control. The person who committed the first moral evil of cyanide poisoning, for example, must have known that his giving cyanide to his victim with the intent to kill would result in his victim's death. However, he could not have had this knowledge on the basis of past instances of intentional cyanide poisonings for which some created agent was morally responsible, since, ex hypothesi, this is the first instance of such poisoning. It must have been, instead, that he knew that his giving his victim cyanide with the intent to kill would result in his victim's death because of past instances in which accidental ingestion of cyanide had led to death. His moral knowledge must have been based on knowledge of past natural evils, in other words. And in order for his knowledge of these instances of cyanide ingestion to ground his relevant

\footnotetext{
13 This abbreviated remark may lead some readers to think that I am here failing to note an important development in Swinburne's thinking about the relationship between natural evil and moral knowledge. Specifically, while Swinburne early in his career maintained that natural evil was necessary for moral knowledge, he later retreated to the weaker view that permitting natural evil is only the best way for God to ensure that moral knowledge is attained [see (Gelinas 2009) for discussion of this development, with references]. However, the view expressed in the text is crafted to avoid this mistake. What is being affirmed in the text is not simply that natural evil is necessary for moral knowledge, but rather that natural evil is necessary if moral knowledge that enables the exercise of significant control to be achieved. One of the reasons Swinburne thinks that it is best for moral knowledge to be achieved via natural evil is that this is the only way for moral knowledge to be achieved so that it still enables the exercise of significant control.

${ }^{14}$ It is important to briefly note the relationship between moral good, moral evil, and exercising significant control. Exercising significant control is necessary for any moral good or moral evil, and any exercise of significant control is either a moral good or a moral evil. This also illuminates the relationship between significant control and moral responsibility. Since all acts for which a person is morally responsible are either moral goods or moral evils, all acts for which a person is morally responsible are acts whereby she exercises significant control.
} 
moral knowledge regarding the potential effects of his own distributions of cyanide, the sample of accidental cyanide deaths of which he knows must be fairly robust. For, as Swinburne explains at length, the inductive sample of evils on which one's moral knowledge is based will yield surer knowledge to the extent that this sample includes a larger number of evils and to the extent that these evils are closer in proximity to the agent's experience.

Finally, Swinburne argues that the range of past known natural evils that there are expands the range of significant control that human persons can exercise. This is because the range of past known natural evils that there are expands the range of ways that human persons have opportunity to benefit or harm themselves and others. If, for example, the only past natural evils there have been were accidental deaths from cyanide ingestion, then knowledge of past natural evils can only yield to human persons the opportunity to exercise significant control with respect to their acts of cyanide distribution. However, if human persons also know of many other, diverse past natural evils, this can yield a wider range of opportunities to exercise significant control. Swinburne maintains that a good God would presumably place some limit on the range of opportunities that human persons have to inflict or avoid inflicting harm on one another. Yet, it is not obvious, he claims, that the range of opportunities that human persons in fact have in our world to harm or avoid harming one another is beyond what a good God would allow.

Let the foregoing suffice as a presentation of central themes from Swinburne's free will theodicy for natural evils. My proposal here is that this theodicy from Swinburne, while developed from an explicitly libertarian perspective, can nonetheless straightforwardly be appropriated by a theological determinist. Indeed, the basic strategy of Swinburne surveyed here can be employed by the theological determinist to at least partially account not only for natural evils of the kind Swinburne has in mind but also, with modifications, for certain evils brought about through human activity, including many moral evils. I will identify four ways in which Swinburne's strategy can be fruitfully adapted by theological determinists.

First, the theological determinist can employ Swinburne's strategy to account for natural evils of the same kind that Swinburne has in mind. With Swinburne, she too can affirm that exercising significant control-albeit of a compatibilist variety - requires satisfying a certain epistemic condition, such as reaching a threshold of evidence concerning the potential effects of one's acts for good and ill. Those theological determinists can affirm the necessity of an epistemic condition for exercising significant control is abundantly clear from recent literature discussing the epistemic condition on moral responsibility. As Timpe writes, 'most extant accounts of moral responsibility,' whether they affirm that free action is compatible with causal determinism or not, 'have two things in common: a control condition and an epistemic condition (Timpe 2011: 5).' The requirement of an epistemic condition on moral responsibility 'cuts across the traditional incompatibilist/compatibilist divide (6).' Just as compatibilits, including theological determinists, can affirm an epistemic condition on moral responsibility, they can affirm an epistemic condition on exercising significant control: an agent can only exercise significant control if she meets a threshold of evidence for thinking that some of her potential acts would lead to goods and that others would lead to bads. ${ }^{15}$

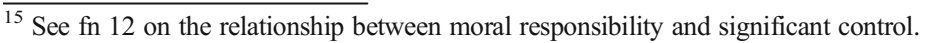


Moreover, with Swinburne, the theological determinist can also affirm that free action requires that one has reason both for and against the act one chooses. Swinburne gives no reason for thinking that his view about the relationship between free action and reasons-possession is the unique provenance of libertarians. And, indeed, much of the literature on developed compatibilist theories of free action is deeply concerned with the relationship between reasons and free action. ${ }^{16}$ My simple suggestion here is that the theological determinist adopts Swinburne's own view that in order to perform a morally good act freely, the actor must have both reason to perform that act and reason to perform a wrong act instead. If the theological determinist adopts this view from Swinburne, she can conclude, just as he does, that satisfying the epistemic condition necessary for exercising significant control over our destinies will require the past occurrence of natural evils. For, the only other alternative for satisfying this epistemic condition would involve direct divine revelation, and such direct divine revelation would ensure that persons only had reason to do what is right and did not have reason to do what is wrong. Thus, just like Swinburne, the theological determinist can maintain that in order for persons to exercise significant control over their destinies, there must be past natural evil knowledge of which puts these persons in the appropriate epistemic relation to the effects of their potential acts for good and ill while preserving their freedom. This is a first way in which Swinburne's strategy can be adapted by theological determinists.

There are also three additional ways in which theological determinists can modify Swinburne's epistemic theodicy in order to account for certain evils brought about through human activity, including moral evils. To see a first way, notice that when making decisions about how to exercise control, we are not only concerned with how our potential acts will affect the pleasure or pain experienced by others (which tends to be the focus of Swinburne's discussion) but also with whether our acts might influence others to commit morally wrong acts or inspire them to perform morally right acts, to develop virtuous or vicious characters. ${ }^{17}$ In other words, we are concerned with how we exercise control over the influence we have on the moral quality of others' lives. Yet, following Swinburne's epistemic theodicy, if we are to exercise significant control over the influence we have on the moral quality of others' lives, then we must possess sufficient evidence concerning how our potential acts will influence the moral quality of others' lives for good or ill. We must, for instance, meet thresholds of evidence concerning how our potential acts will influence the morally right or morally wrong acts of others. Yet, satisfying this epistemic condition will need to be achieved through induction from past cases, for the familiar reasons given above. Our evidence concerning how our potential acts will influence others to perform moral rights or wrongs, or to cultivate virtuous or vicious characters will be drawn from our knowledge of past instances in which the behaviors of some human persons influenced other human persons in these ways. However, it is clear that in order to have the requisite

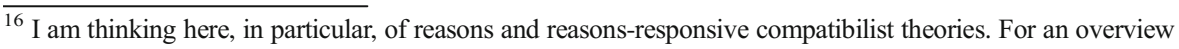
of these, see (McKenna and Coates 2015, Sections 5.3 and 5.4).

${ }^{17}$ Swinburne does, in fact, very briefly anticipate this point. He remarks, 'Clearly too the greater the share in his creative work which a God chooses to give to men, the greater the powers to benefit and to harm each other he must give to them. He must for example not merely give men the power to bruise each other, but also give ment he power to become heroin addicts, to persuade other men to become heroin addicts, and to drop atom bombs (1978: 296, emphasis added).'
} 
kind of inductive sample of past instances in which the behaviors of some human persons influenced others to perform moral wrongs or to develop vicious characters, there must be past moral wrongs and past instances of vicious character development. Thus, the resources of Swinburne's theodicy can be straightforwardly adapted by theological determinists to at least partially account for certain moral evils - specifically, moral evils the occurrence of which was influenced by the controllable behavior of human persons other than the evildoer.

The resources of Swinburne's epistemic theodicy can be further adapted by theological determinists to account for other moral evils that need not have been influenced by the controllable behavior of human persons other than the evildoer. To see one way in which this may be achieved, consider the act of identifying with certain features of character rather than others. Identification with certain features of character, such as patience, love, or thankfulness rather than others such as impatience, hatefulness, and ingratitude plausibly plays a significant role in an agent's self-creation - in the way she governs what sort of persons he becomes. Acts of identification, then, are good candidates for acts through which an agent can achieve the freedom good of exercising significant control over her self-formation. ${ }^{18}$ Employing the resources of Swinburne's theodicy, however, theological determinists might argue that if acts of identification are to make possible such freedom goods, then there must be past moral evils.

To see why Swinburne's theodicy can be adapted to show that acts of identification can lead to the freedom good of exercising significant control over one's self-formation only if there are past moral evils, we need to recall and apply four elements from Swinburne's epistemic theodicy surveyed above. First, given Swinburne's theodicy, if the act of identification is to be one whereby the agent exercises significant control, then it must be that this act is performed in the face of an opportunity to perform both an action of identification that would lead to a significant good and an action of identification that would lead to a significant bad. ${ }^{19}$ Second, if the act of identification was performed in the face of an opportunity to perform an action of identification that would lead to a significant bad, then it must have been that this opportunity was an opportunity to identify with features that tend to produce actions that lead to bads. For plausibly, an action of identification will only lead to significant bads if it is an act of identifying with features that tend to produce acts that lead to bads. ${ }^{20}$ However, third, if the act of identification was performed in the face of an opportunity to identify with features which tend to produce acts that lead to bads, then the actor must have known that there were features with which she could identify which tend to produce acts that lead to bads. And, fourth and finally, it will follow given Swinburne's theodicy that such knowledge could only be achieved via induction from past instances in which such features produced acts that led to bads. For in order to know that identifying with a

\footnotetext{
${ }^{18}$ Several compatibilists have employed acts of identification to account for various freedom goods. For example, Bratman (2007) argues that the freedom good of autonomous action can only be achieved via acts of identification.

${ }^{19}$ When introducing Swinburne's ideas above, I said that, on his view, for a person to exercise significant control in a domain she must have opportunity to do good acts in that domain as well as opportunity to do bad acts in that domain. Here, I apply this idea to the specific domain of acts of identification.

${ }^{20}$ To be a bit more ecumenical here, one might allow that acts that 'lead to' bads can include acts that just are bad. Swinburne himself tends not to distinguish acts that just are bad from acts that lead to, in a more strictly causal sense, bads. As such, he appears to endorse a consequentialist account of bad action.
} 
certain feature will potentially result in acts brought about by that feature that lead to bads, one must know of past instances in which this feature produced acts that led to bads. If, for example, a person is to exercise significant control through identifying with compassion for others rather than contempt, she must know of past instances in which compassion or contempt produced actions that led to bads.

Moreover, it is plausible that these past instances in which the relevant feature is known to have produced acts that led to bads must include moral evils. They cannot all be instances in which this feature produced acts that led to bads, where no person was morally responsible for those bads. For when a person decides to identify with a certain feature rather than others, her decision just is a decision aimed at cultivating or maintaining a character in which this feature rather than the others play the right sort of role to give rise to actions over which she exercises significant control and so is morally responsible. What she needs to know, then, is what kinds of actions this feature tends to give rise to when it plays the right sort of role to give rise to actions over which persons possessing it exercise significant control. But then, the past cases which give rise to her knowledge must include past cases where the relevant feature gave rise to moral evils - acts that led to bads for which the agent possessing the feature was morally responsible. Thus, Swinburne's theodicy can be adapted by theological determinists to show that if there are to be freedom goods that require the exercise of significant control through acts of identification, there must be moral evils.

We have seen, then, that Swinburne's epistemic theodicy can be adapted by theological determinists in order to at least partially account not only for the same kinds of natural evils that were the original topic of his theodicy but also for certain moral evils. It can be adapted to account for moral evils which were brought about through the influence of the behavior of human persons other than the evildoer, and it can be adapted to account for moral evils that provide knowledge necessary for persons to exercise significant control over their self-formation through acts of identification.

I propose a fourth and final way in which Swinburne's epistemic theodicy can be adapted by theological determinists to account for moral evils. Recall Swinburne's view that a person's control over her destiny is expanded when she knows of a greater range of past evils. We have, for example, greater control over our destinies if we know not only of past instances of accidental cyanide poisonings but past instances in which persons accidentally fell off of cliffs and were thereby injured. For, this knowledge expands the range of morally significant options open to us. I propose that the theological determinist might adapt this idea and propose that when a person knows that she herself or another human person has performed a moral evil in the past, this can uniquely expand the range of morally significant options available to her, thereby expanding the range of freedom goods achievable by her.

To see why this proposal is attractive, begin by noticing that the epistemic position in which a person stands to the good and bad effects of her potential acts comes in degrees. Past instances in which cyanide has accidentally been ingested and death has followed provide evidence that if one is to put cyanide in another's drink intending his death, he will die as a result. Enough past instances of accidental death by cyanide ingestion may provide sufficient evidence for one to meet the threshold of evidence necessary for satisfying the epistemic condition necessary for exercising significant control over one's behaviors with respect to cyanide. But, as Swinburne himself is quick to admit, accidental deaths by cyanide do not provide as good evidence 
concerning the potential effects of putting cyanide in someone's drink with the intent to kill him as past instances in which either oneself or others put cyanide in someone's drink with the intent to kill him. For, in the latter instance, the cases which form the inductive basis of one's moral knowledge are more similar to one's own experience. Thus, if there are past cases in which human persons have intentionally given cyanide to others with the intent of killing them (thus performing moral evils), this will provide one with stronger evidence that if one is to intentionally give cyanide to someone with the intent to kill, he will die as a result. However, possessing such strengthened evidence, I propose, opens up a greater range of morally significant options for the actor. This is because, other things being equal, the stronger the evidence one has for thinking that acting with the intention of bringing about a bad will succeed in bringing about the bad, the worse an action one performs when acting with the intention to bring about that bad. For example, the stronger the evidence one has that giving cyanide with the intent to kill brings about death, the worse an action one performs when one gives cyanide with the intent to kill. Accordingly, more generally, when human persons have evidence concerning the occurrence of moral evils committed by themselves or others, this opens up a greater range of morally significant options to them. They can do worse evils than they otherwise could, since they will have stronger evidence of the success of their potential evil-aimed acts. They can, for example, commit acts of poisoning knowing full well that the poisoning will lead to death and not just actions of poisoning knowing pretty well that poisoning will lead to death.

Now, I do not intend to argue here for any particular view about exactly how far a good God would aim to expand the range of morally significant options available to human persons. I will not argue, for example, that we have more reason to expect that this God would aim to give human persons the option of performing moral evil acts of a type they know to have already been committed than that this God would not aim to provide human persons with this option. I simply note that knowing of past moral evils does uniquely expand the range of morally significant options open to an actor, and, as Swinburne himself affirms, it is not clear just how far a good God would aim to expand the morally significant options for human persons. As he affirms, there is presumably some limit, but it is difficult to say with much confidence where we should expect this limit to fall. This is the final way of adapting Swinburne's epistemic theodicy; then, I take to only provide a weak sort of theodicy. I do not take it to provide an account of why God plausibly would permit the moral evils with which it is concerned, but only to provide one reason why God might permit them. God might permit some moral evils because doing so is necessary for expanding the range of significant control that human persons can exercise, and it is a significant freedom good for human persons to exercise expanded control.

Swinburne's epistemic theodicy, then, proves especially fruitful for theological determinists. They can adapt his theodicy to account for the same natural evils that he is concerned with in almost exactly the way he does. They can adapt it to at least partially account for moral evils which are influenced by the behavior of persons other than the evildoer. They can employ it to at least partially account for moral evils knowledge of which is necessary for achieving freedom goods through acts of identification. And, they can employ it to offer a 
weak theodicy for moral evils knowledge of which expands the range of morally significant control persons are able to exercise.

\section{Greater Moral Goods Free Will Theodicies for Theological Determinists}

The final theodicy I will address is that provided in Plantinga's (1978) Molinist response to the logical problem of evil. Plantinga only aims to provide a weak sort of theodicy, an account of how it could be that God was unable to bring about a greater balance of moral goods than moral evils without permitting some moral evils. This weak sort of theodicy is often called a defense. Plantinga presents his defense as explicitly committed to libertarianism. He writes, 'If a person $\mathrm{S}$ is free with respect to a given action, then he is free to perform that action and free to refrain; no causal laws and antecedent conditions determine either that he will perform the action, or that he will not (Plantinga 1978: 167).' However, I aim to show here two ways in which a theological determinist might adapt Plantinga's strategy to provide free will theodicies of her own.

Plantinga's basic strategy is to propose that it is possible that there is a group of facts with two features. First, the truth value of the facts is independent of divine volition. God cannot do anything about these facts; God simply confronts the facts, we might say, at the logical moment of his creative decision. Second, the facts are such that they ensure that if God is to create a world containing certain kinds of freedom goods, God must permit there to be moral evils. In particular, Plantinga proposes that the facts are such that they ensure that if God is to create a world containing a greater balance of moral goods (and, moral goods are by definition freedom goods) than moral evils, God must permit some moral evils.

In Plantinga's account, the facts that he proposes might have these two features are counterfactuals of creaturely freedom. These facts specify how created agents would freely behave under a complete set of circumstances. As an illustration, one such fact would report how you would freely behave in exactly the circumstances in which you currently find yourself. On Plantinga's view, there is a complete set of such facts in any possible world. For any possible created agent $\mathrm{S}$, any action $\mathrm{A}$, and any complete set of circumstances $\mathrm{C}$, it is either true that were $\mathrm{S}$ in $\mathrm{C}, \mathrm{S}$ would freely do $\mathrm{A}$, or it is true that were $\mathrm{S}$ in $\mathrm{C}, \mathrm{S}$ would not freely do A. On Plantinga's view, the truth values of these counterfactuals of creaturely freedom are not only independent of divine volition but they can vary from one possible world to another. As we might put it, when God decides to create, the counterfactuals of creaturely freedom happen to be one way, though they could have been another, and the way they are is not up to God. Plantinga proposes that it could have been that the complete set of counterfactuals of creaturely freedom happened to have a combination of truth values such that if God is to create a world containing more moral good than moral evil, God will have to permit moral evils. Since it is not unreasonable to think God might prefer to create such a world rather than to refrain from creating, it is not unreasonable to think that it might have been that God created a world containing moral evils, because it was only by doing so that he could create a world containing the freedom good of a greater amount of moral goods. 
My proposal here is that there are two ways in which a theological determinist can adapt the basic strategy of Plantinga's free will theodicy. The two ways differ with respect to which facts the theological determinist proposes play the role played by the counterfactuals of creaturely freedom in Plantinga's own theodicy.

Perhaps somewhat surprisingly, the first proposal is that the facts that play the role played by the counterfactuals of creaturely freedom in Plantinga's theodicy are these very counterfactuals of creaturely freedom. In other words, the proposal is that theological determinists adopt all of the details of Plantinga's proposal, except for his commitment to libertarianism. We might call such a theological determinist a compatibilist Molinist (since she thinks that free actions are compatible with causal determinism), where we would call Plantinga an incompatibilist Molinist (since he thinks free actions are incompatible with causal determinism).

As it turns out, compatibilist Molinism is not without motivation. Indeed, some of the most challenging criticisms of Plantinga's (and others') Molinism have argued that this Molinist view is inconsistent with an incompatibilist theory of free action, and so inconsistent with the libertarian view that Plantinga affirms. In particular, I have in mind arguments that conclude that if there were true counterfactuals of creaturely freedom, their truth would imply that any free actions of creatures were compatible with causal determinism. ${ }^{21}$ These arguments proceed by noting that if there were true counterfactuals of creaturely freedom, they would be past facts. But, the truth of these past facts, together with the truth of past facts concerning God's creative decisions to actualize the circumstances specified in the antecedents of these counterfactuals of creaturely freedom, entails that the free acts reported in the consequents of these conditionals occur as they are reported. Thus, each so-called 'free' act is the logical consequence of past facts. Yet, this is sufficient for the thesis of causal determinism to be true, at least as it concerns 'free' acts. For, the thesis of causal determinism simply states that each future fact is the consequence of past facts and the laws of nature. Yet, any fact that is the consequence of past facts alone is also the consequence of those past facts together with the laws of nature, since logical consequence is monotonic (i.e., if $\mathrm{p}$ is a logical consequence of $\mathrm{q}$, then for any $\mathrm{r}, \mathrm{p}$ is a logical consequence of $\mathrm{q}$ and $\mathrm{r}$ ). Accordingly, if the acts specified in the consequents of counterfactuals of creaturely freedom really are free acts, then compatibilism is true. For, the occurrence of these free acts is compatible with these acts being causally determined.

Incompatibilist Molinists of course have their responses to such arguments. Nonetheless, such arguments are taken by many contemporary philosophers to present a serious challenge to incompatibilist Molinism. My own impression is that, typically, philosophers who find these arguments against incompatibilist Molinism persuasive take this to be a reason to give up on pursuing the sort of free will theodicy defended by Plantinga. Yet, a different option-the option that interests me here-is the option of taking such arguments to instead motivate compatibilist Molinism. Grant that these arguments succeed in showing that the truth of counterfactuals of creaturely freedom would entail that any free acts are compatible with causal determinism. But keep Plantinga's Molinist

${ }^{21}$ For a recent defense of such arguments, see (Cohen 2015). 
free will theodicy. Simply affirm, as the theological determinist does, that all the free acts that exist are causally determined.

On the compatibilist Molinist view I am proposing, God, in the moment of creative decision, is confronted with the truth of a complete set of counterfactuals of creaturely freedom. The truth values of these counterfactuals are not up to God. Indeed, as on some incompatibilist Molinist views (e.g., Flint 1998), the counterfactuals of creaturely freedom are simply brute facts. ${ }^{22}$ As with Plantinga's Molinism, it could have been that the combination of truth values of these counterfactuals of creaturely freedom was such that God was only able to create a world containing the freedom good of a greater balance of moral goods than moral evils if God permitted moral evils. And, as on Plantinga's Molinism, it is not unreasonable to think that God might have preferred, given that this was how things were, to create a world containing more moral good than moral evil than to not create at all. In this way, the theological determinist simply employs Plantinga's own story, minus its libertarianism, to explain how it could have been that there were freedom goods God could only achieve by permitting moral evils.

How plausible is the compatibilist Molinist story in comparison to Plantinga's original incompatibilist Molinist story? The answer to this question will turn on whether it is any less plausible for the theological determinist to affirm the existence of counterfactuals of creaturely freedom with truth values independent of the divine will than for the incompatibilist to do so. Exploring this topic in detail is, I think, a topic ripe for further future exploration. It is not something I can attend to with sufficient care here. Nonetheless, I will engage briefly with one attempt to show that incompatibilist Molinism is on better footing in affirming these counterfactuals than is compatibilist Molinism. ${ }^{23}$ By doing so, I hope to illustrate that arguing for the superiority of incompatibilist Molinism over compatibilist Molinism may not be as simple as some readers may initially suspect.

One might think that the incompatibilist Molinist has the following significant advantage over the compatibilist Molinist. She, but not her compatibilist cousin, can offer a straightforward and attractive explanation of why the counterfactuals of creaturely freedom cannot be subject to the divine will. The explanation is just that these counterfactuals are facts about the free acts of creatures. But, since the incompatibilist Molinist is an incompatibilist, she will affirm that facts about the free acts of creatures cannot be subject to the will of anyone other than those creatures they are about. And so, these facts cannot be subject to the divine will. However, a compatibilist Molinist, by contrast, cannot say that counterfactuals of creaturely freedom cannot be subject to the divine will simply because they are facts about the free actions of creatures, and facts about the free actions of creatures cannot be subject to the will of anyone other than those creatures.

\footnotetext{
${ }^{22}$ Perhaps, this does not entail that they are not up to human persons. I take it that the view of some incompatibilist Molinists is precisely this: that these facts, while brute, are nonetheless up to those human persons that they are about. I see no reason for thinking that a compatibilist Molinist could not affirm this very same view. Indeed, the sense of 'up to' that is appealed to by incompatibilist Molinists in order to explain how these brute facts are up to the persons they are about is one that is well in line with what traditional compatibilist have said about how our actions are 'up to' us in the sense required for free action. See discussion in (Flint 2009) on in what way these facts are 'up to' to persons they are about.

${ }^{23}$ Thanks to Robert Hartman for raising this possibility in discussion.
} 
While tempting, this way of arguing that incompatibilist Molinism is more plausible than compatibilist Molinism is misleading. There are lots of ways for facts to be about the free actions of creatures. But, only some of these ways for facts to be facts about the free actions of creatures are ways where it is more plausible given incompatibilism than compatibilism that these facts cannot be up to the will of anyone other than those whom the facts are about. In particular, what is plausible is that it is more plausible given incompatibilism than compatibilism that facts that simply report that some creature performed some free act cannot be up to the divine will, since they cannot be up to the will of anyone other than the actor whom they are about. But, the counterfactuals of creaturely freedom are not about free acts in this way. They do not simply report that some creature performs some free act. Rather, they report what a creature would freely do in a set of circumstances. And it is not at all clear why it would be more plausible given incompatibilism than compatibilism that facts that are about the free actions of creatures in this way cannot be subject to the divine will.

That this particular attempt to argue that incompatibilist Molinism provides a more plausible free will theodicy than compatibilist Molinism fails does not entail that there is no way to show that incompatibilist Molinism is more plausible than compatibilism Molinism. Nonetheless, its failure does illustrate that arguing that incompatibilist Molinism is superior to compatibilism Molinism may be more difficult than some readers might initially assume. This should be enough to generate interest among readers in pursuing the project of comparatively evaluating incompatibilist and compatibilist versions of Molinism in the future. I offer, then, compatibilist Molinism as one way in which theological determinists can adapt Plantinga's strategy to offer a free will theodicy.

Turn now to a second way in which theological determinists might adapt Plantinga's free will theodicy. On this approach, the facts that play the role played by the counterfactuals of creaturely freedom in Plantinga's Molinist theodicy are not counterfactuals of creaturely freedom. They are instead necessary truths constituted by or derivable from laws of nature about human persons. They state, for example, that, necessarily, if human persons develop in such a way as to form the kinds of complex social arrangements necessary for producing freedom goods of collective exercises of significant control, then these human persons will commit moral evils along the way. ${ }^{24}$ Or, they may instead make similar, more specific statements about particular human persons in particular social arrangements necessary for particular exercises of collective responsibility committing particular moral wrongs. When I refer to such facts as either constituted by or derivable from laws of nature, I intend to be supposing a conception of laws of nature, recently given much attention, ${ }^{25}$ according to which laws of nature are more than mere Humean generalizations, but are instead made true by the nature of those entities they are about. It is human nature, on this proposal, which accounts for the truth of the laws from which the facts I have in mind are either constituted or derived. On the view I am proposing, it is because human nature is the way that it is that human persons cannot develop the kinds of complex social relations necessary for

\footnotetext{
${ }^{24}$ The literature on the precise nature of collective action and responsibility is vast and complex [for an overview, see (Smiley 2010)]. I do not intend here to adopt any particular theory of the nature of collective action and responsibility, but simply to refer to the phenomena; however, they are best understood.

${ }^{25}$ See, e.g., (Heil 2005) and (Bird 2007).
} 
achieving freedom goods of collective exercises of significant control without committing some moral evils. ${ }^{26}$ It is moreover proposed that these facts that are constituted by or are derivable from facts about human nature have the two features of Plantinga's counterfactuals. They are independent of divine volition, and they are such that they ensure that God is not able to bring about a world containing certain freedom goods without permitting moral evils. The particular freedom goods that are in focus here are freedom goods that require the collective exercise of significant responsibility. The proposal, more fully, is that, in light of the facts about human nature, God could not have achieved a world with a greater balance of moral goods than moral evils, where the total set of moral goods included goods requiring collective exercises of significant control, without permitting moral evils. ${ }^{27}$

We might call the foregoing adaptation of Plantinga's free will theodicy the bad human nature theodicy. One important way in which it differs from the compatibilist Molinist theodicy is that it allows the theological determinist to maintain that all contingent facts are subject to the divine will. This is because the facts that play the role of counterfactuals of creaturely freedom in this theodicy are not contingent facts. This difference is worth pointing out because many who have been attracted to theological determinism of the kind in view in this paper have also wished to maintain that all contingent facts are subject to the divine will. Indeed, the term 'theological determinism' is frequently reserved for just such a view.

If we wish to assess the comparative merits of this bad human nature theodicy versus Plantinga's original Molinist theodicy, the central question will concern whether it is more plausible to affirm the existence of Plantinga's counterfactuals of creaturely freedom than to affirm the existence of the facts featured in the bad human nature theodicy. We have already seen that there is a large literature devoted to assessing the plausibility of affirming the existence of Plantinga's counterfactuals, including arguments aiming to show that their existence is implausible, or that it is implausible given incompatibilism. My focus here will be on assessing the plausibility of the facts featured in the bad human nature theodicy. And, while I cannot offer a completely thorough assessment of the plausibility of their existence here, I will offer some comments in favor of their plausibility and respond to some objections to their plausibility, inviting readers to join with me in more fully evaluating these considerations and others in the near future.

One important observation on behalf of the existence of the facts featuring in the bad human nature theodicy is the empirical evidence. Every known historical instance of a

\footnotetext{
${ }^{26}$ It may be that it is possible for human beings to eventually develop to a point where they can engage in collective exercises of significant control without any longer committing moral evils - that human beings are perfectable, in other words - but the present proposal is that the road to such perfectability necessarily includes moral evils.

${ }^{27}$ One might object here that the language of 'permission' is at best misleading. Surely, the God of the bad human nature theodicy is doing something other than or more than merely permitting or allowing moral evils - this God contributes in a more positive causal way to bringing these evils about. Readers who find this line of objection persuasive are invited to replace the language of 'permission' used here with alternative language, such as the language of 'bringing about.' The debate about the best way to understand what it is to permit or allow something, and whether the God of the bad human nature theodicy is best described as permitting moral evils, is not a debate on which I intend to take a stand. For a defense of the claim that such a God is best described as permitting or allowing moral evils, see Helm's contributions in (Hasker and Helm 2004).
} 
human community that has developed the kinds of social arrangements necessary for collective exercises of significant responsibility has been one in which moral evils were committed along the way to this social formation. The facts that feature in the bad human nature theodicy provide a powerful explanation of this empirical evidence. The reason every known historical case in which a human community has developed the kinds of social arrangements necessary for collective exercises of significant responsibility has been one in which moral evils have been committed along the way is that this is simply part of human nature. This is how things have to be for human persons, given the way human persons are. (Indeed, more broadly, the advocate of the bad human nature theodicy will likely go even further to claim that this is how things must be for created beings capable of collective exercises of significant control more generally. For, the only empirical evidence we have concerning any beings of this kind indicates that none of those beings can achieve freedom goods of collective exercises of significant control without committing moral evils along the way. Yet, it is difficult to identify a reason for thinking that human beings are unique in this respect among other creatable beings - that there is special reason to think that humans would be bad. Indeed, Plantinga's own original Molinist theodicy treats human beings on part with other creatable beings with respect to the kind of badness that features in his viewtransworld depravity. Likewise, an advocate of the bad human nature theodicy will likely think that what she says for humans goes for other creatable beings as well-hers is a 'bad creatable beings' theodicy.)

To just what extent does the empirical evidence favor the bad human nature theodicy? One strategy for trying to show that it does not favor it substantially is to argue that the bad human nature account of the relevant empirical evidence is less attractive than accounts of this evidence only available to libertarians. And, indeed, there is one especially common such explanation in the philosophical literature of theists who are committed to libertarianism. It is the proposal that human nature as such is not such as to make the facts featuring in the bad human nature theodicy true, but rather that corrupted human nature is such as to make these facts true. And, this corrupted human nature resulted as a consequence for moral evils committed by uncorrupted human persons, where these moral evils involved the commission of free acts that were incompatible with causal determinism. I am referring, of course, to a libertarian understanding of the doctrine of the fall. ${ }^{28}$

One important reason for favoring this fallen human nature account of the relevant empirical evidence is that it appears to cohere better with the fact that it is conceivable that there be a society of human persons which develops the relations necessary for collective exercises of significant control without there being moral evils committed along the way. If conceivability is evidence for possibility, then the conceivability of such a society provides evidence against the bad human nature explanation of the relevant empirical data. For, the bad human nature account of the empirical evidence entails that it is not possible that there would be a human society with the sorts of relations necessary for exercises of significant responsibility without the members of this society committing moral evils during its formation. The libertarian account of this evidence, by contrast, is arguably consistent with the possibility of there being human persons who achieve all manner of freedom goods without there being any moral evils.

${ }^{28}$ For recent discussion of the doctrine of the fall, see (Crisp 2009). 
Indeed, this possibility was a shared commitment of both Plantinga and his interlocutors at the time of his writing. Plantinga's view was that it was possible that the counterfactuals of creaturely freedom were such that God could not achieve a world with certain freedom goods without there being moral evils, but, because these counterfactuals are contingent, it was also possible that God could achieve a world with those same freedom goods without there being moral evils. The latter possibility, however, is denied by the bad human nature theodicy. At least, it is denied if the moral goods are to include moral goods that require the collective exercise of significant control. Accordingly, if conceivability is evidence of possibility, then there is evidence favoring the libertarian, fallen human nature account of the relevant empirical evidence over the bad human nature account.

There is of course a significant literature devoted to assessing whether and to what extent conceivability is evidence for possibility. ${ }^{29}$ And within this literature, there are dissenting and cautionary voices, urging us to take care about how quickly we grant that something is possible because it is conceivable. There are also voices urging us to take care with respect to what is required for something to be genuinely coherently conceivable. And indeed, in the broader literature on theodicy, such cautionary voices are often cited, particularly by those who defend natural law theodicies according to which God's creating a world with optimal laws of nature for enabling freedom goods was not possible without evils of the sort found in our world. Notably, those who defend such natural law theodicies are frequently explicitly committed to a libertarian account of free action. ${ }^{30}$ Yet, I suggest here that these observations about the relationship between conceivability and possibility can be employed equally fruitfully by the advocate of the bad human nature theodicy to at least partially rebut the present argument for favoring the fallen human nature account to her own.

Even if the defender of the bad human nature theodicy grants that the conceivability of human societies in which there are freedom goods of collective exercises of significant responsibility without moral evils is evidence for the possibility of this and therefore evidence against her theodicy, she can still, in light of the foregoing reservations about the relationship between conceivability and possibility, maintain that this evidence is weak and defeasible. She might on this basis grant that while, given the evidence from conceivability alone, her theological determinist theodicy is not equally as plausible as Plantinga's original, it is still worthy of further investigation. And, she might attempt to show that there is counterevidence against conjoining Plantinga's original theodicy with the fallen human nature explanation of the empirical evidence of moral evil which can neutralize the force of the evidence from conceivability that favors his view over her adaptation.

Such counterevidence is not terribly difficult to locate. For instance, there are of course classical objections to the fallen human nature account itself. It has proven difficult, for example, for advocates of this view to provide an attractive account of how it could be that corrupt human nature could be a consequence of the moral wrongdoing of incorrupt human persons without requiring a view on which God unjustly punishes some for the wrongdoing of others. One prominent view about how it is that the wrongdoing of uncorrupt human persons leads to the corruption of human nature is that

\footnotetext{
${ }^{29}$ See, e.g., (Hawthorne and Gendler 2001).

${ }^{30}$ See, e.g., (van Inwagen 2006) and (Reichenbach 1982).
} 
the corruption of subsequent human nature is a divine punishment for this original wrongdoing. But, if so, it seems this punishment is unjust, since persons who committed no wrong are made to have a corrupt nature on account of wrongs committed by others. If, however, divine punishment is not the mechanism whereby the wrongdoing of uncorrupt human persons leads to the corruption of subsequent human nature, one wonders what this mechanism could be.

Additionally, there is a concern about conjoining Plantinga's original theodicy with the fallen human nature view. For, there is a tension between Plantinga's original theory about the independence of counterfactuals of creaturely freedom with the way in which the fallen human nature account of the empirical evidence of wrongdoing appears to require that such facts be dependent on past human wrongdoing. Recall on Plantinga's original Molinist theodicy, the counterfactuals of creaturely freedom that specify how an agent would behave in a complete set of circumstances are not subject to the divine will. Nor are they subject to the will of persons other than the human actor whom they are about. Yet, the libertarian account of the empirical evidence of pervasive human wrongdoing requires that this evidence is explained by the fact that all human persons have corrupt natures, and their having corrupt natures is a consequence of the wrongdoing of uncorrupt human persons. If, however, the fact that all human persons subsequent to the original wrongdoers have corrupt natures is to explain the empirical evidence for human wrongdoing, it will plausibly entail, and explain, counterfactuals of creaturely freedom regarding these corrupt human wrongdoers. The reason it is the case that were there to be a community of existing human persons which developed the kinds of sophisticated arrangements necessary for collectively exercising significant control, there would be wrongs committed along the way, is that all existing human persons have corrupt natures as a result of the original human wrongdoers. But, then, the truths of these counterfactuals of creaturely freedom are not, pace Plantinga's original theodicy, independent of the will of persons other than the persons they are about. They are instead dependent on the original wrongdoers.

Given the strategies available to the advocate of the bad human nature theodicy for neutralizing the evidence from conceivability against her view, the bad human nature theodicy constitutes a theological determinist adaptation of Plantinga's original Molinist theodicy which is not clearly on worse footing than Plantinga's original, when the latter is conjoined with a leading libertarian explanation of the empirical evidence of pervasive human wrongdoing. Besides this one libertarian account of this empirical evidence discussed above, there may be others. Some of them may, when conjoined with Plantinga's original Molinist theodicy, produce a view that is more plausible than the bad human nature adaptation of Plantinga's theodicy. ${ }^{31}$ This, however, is yet to be seen. Until it is seen, I propose that it is not clear that it is less plausible to affirm the existence of the facts that figure in the bad human nature theodicy than it is to affirm the

\footnotetext{
${ }^{31}$ One proposal is to simply agree with the bad human nature theodicy that human nature is bad in the relevant respect, but to propose that other creatable beings are not bad in this way. God could have created non-humans that achieved freedom goods of collective exercises of significant control without committing moral evils. One problem with this proposal has already been noted in a parenthetical comment in the text above. An additional problem is as follows. Surely advocating this view does nothing to put Plantinga's original theodicy in a better position than the bad human nature theodicy. For, an advocate of Plantinga's theodicy who embraces this view will face the problem of explaining why God created bad humans rather than other, not-so-bad creatable beings just as much as her theological determinist counterpart will.
} 
existence of the facts that figure in Plantinga's Molinist theodicy. And so, this second theological determinist adaptation of Plantinga's greater moral goods free will theodicy remains worthy of future consideration.

There are two ways, then, that theological determinists might fruitfully adapt Plantinga's Molinist theodicy: by adopting compatibilist Molinism and by adopting the bad human nature theodicy. In neither case, it is clear that the resulting adaptation of Plantinga's theodiciy will be significantly less plausible than his original.

\section{Conclusion}

The aim of this paper has been to make a significant contribution toward challenging a received narrative in contemporary philosophy of religion that theists should adopt libertarianism in order to respond to the problem of evil. I have challenged this narrative by showing that three leading free will theodicies, all of which explicitly affirm a commitment to libertarianism, can be adapted by theological determinists who deny libertarianism in order to produce their own free will theodicies for a wide variety of moral and natural evils. The theodicies I have examined are not an exhaustive compilation of free will theodicies that explicitly appeal to libertarianism. I have not, for example, engaged with free will theodicies committed to libertarianism which also centrally involve a commitment to the claim that God does not know the future free actions of creatures. ${ }^{32}$ Nonetheless, the theodicies examined are among the very most influential free will theodicies involving an explicit commitment to libertarianism which do not require denying God's knowledge of the future free actions of creatures. As such, the success of this paper should, at minimum, weaken the confidence of those who affirm God's knowledge of the future free actions of creatures that they should adopt a libertarian theory of free action in order to adequately respond to the problem of evil. At the same time, I hope it may invigorate investigation into the resources of theological determinists in addressing the problem of evil. ${ }^{33}$

Open Access This article is distributed under the terms of the Creative Commons Attribution 4.0 International License (http://creativecommons.org/licenses/by/4.0/), which permits unrestricted use, distribution, and reproduction in any medium, provided you give appropriate credit to the original author(s) and the source, provide a link to the Creative Commons license, and indicate if changes were made.

\section{References}

Almeida, Michael. (forthcoming). Compatibilism and the free will defense. In Free Will: Theology of Free Will, ed. David Hunt and Hugh McCann.

Bird, A. (2007). Nature's metaphysics: laws and properties. Oxford: Press, Oxford University.

Bratman, M. (2007). Structures of agency: essays. Oxford: Oxford University Press.

Cohen, Y. (2015). Molinists "Still” cannot endorse the consequence argument. International Journal for Philosophy of Religion, 77, 231-46.

Crisp, O. (2009). Original sin and atonement. In Oxford handbook of philosophical theology (Thomas Flint and Michael Rea, pp. 430-51). Oxford: Oxford University Press.

\footnotetext{
${ }^{32}$ E.g., (Hasker 2004).

${ }^{33}$ One way in which future literature might expand upon the work here is by comparing the theodical resources that differing versions of compatibilism offer theists.
} 
Flint, T. (1998). Divine providence: the molinist account. Ithaca: Cornell University Press.

Flint, T. (2009). Divine providence. In Oxford handbook of philosophical theology (Thomas Flint and Michael Rea, pp. 262-85). Oxford: Oxford University Press.

Gelinas, L. (2009). The problem of natural evil I: generic theistic replies. Philosophy Compass, 4(3), 533-59.

Hasker, William. (2004). Providence, evil, and the openness of God. Routledge.

Hasker, W., \& Helm, P. (2004). Does God take risks in governing the world?". In M. Peterson \& R. VanArragon (Eds.), Contemporary Debates in Philosophy of Religion (pp. 218-41). Oxford: Blackwell.

Hawthorne, J., \& Gendler, T. S. (Eds.). (2001). Conceivability and possibility. Oxford: Oxford University Press.

Heil, J. (2005). Dispositions. Synthese, 144(3), 343-56.

Hick, J. (1978). Evil and the God of love (2nd ed.). San Francisco: Harper.

Hick, J. (2001). Soul-making theodicy. In W. Rowe (Ed.), God and the problem of evil (pp. 265-81). Oxford: Blackwell.

Judisch, N. (2008). Theological determinism and the problem of evil. Religious Studies, 44, 165-84.

McKenna, Michael and Coates, Justin. 2015. "Compatibilism." In Stanford Encyclopedia of Philosophy, ed. Edward Zalta. Available at http://plato.stanford.edu/entries/compatibilism/.

McNaughton, David and Eve Gerrard. (2014). "Forgiveness and forgivingness." In The Handbook of Virtue Ethics, ed. Stan van Hooft and Nafsika Athanassoulis. Acumen.

Pereboom, Derk. (2012). Theological determinism and divine providence. In Molinism: The Current Debate, ed. Ken Perszyk, 262-80. Oxford University Press.

Plantinga, A. (1978). The nature of necessity. Oxford: Oxford University Press.

Poston, Ted. (2014). Social Evil. Oxford studies in philosophy of religion, Vol. 5, ed. Jonathan Kvanvig, 20933. Oxford University Press.

Pruss, A. (2013). Omnirationality. Res Philosophica, 90(1), 1-21.

Reichenbach, Bruce. (1982). Evil and a good God. Fordham University Press.

Smiley, Marion. (2010). Collective Responsibility. In Stanford Encyclopedia of Philosophy, ed. Edward Zalta. Available at http://plato.stanford.edu/entries/collective-responsibility/.

Speak, Daniel and Kevin Timpe. (2016). Introduction. In Free Will and Theism: Connections, Contingencies and Concerns, ed. Daniel Speak and Kevin Timpe. Oxford University Press.

Speak, Daniel. (2013). Free will and soul-making theodicies. In The Blackwell Companion to the Problem of Evil, ed. Justin McBrayer and Daniel Howard-Snyder. Blackwell.

Swinburne, R. (1978). Natural evil. American Philosophical Quarterly, 15(4), 295-301.

Timpe, K. (2011). Tracing and the epistemic condition on moral responsibility. Modern Schoolman, 88(1), 528.

Turner, J. (2013). Compatibilism and the free will defense. Faith and Philosophy, 30(2), 125-137.

van Inwagen, P. (2006). The problem of evil. Oxford: Oxford University Press. 